\title{
Pemberdayaan Ibu Pasca Bersalin, Keluarga, tentang PHBS, Perawatan Ibu dan Bayi serta Pencegahan Penularan COVID-19
}

\author{
Islah Wahyuni ${ }^{1}$, Ulfa Hasanah ${ }^{2}$, Novi Yanti ${ }^{2}$, Ifon Driposwana Putra ${ }^{2}$ \\ email : islah fattan@yahoo.co.id \\ ${ }^{1}$ D-III Kebidanan, Stikes Payung Negeri Pekanbaru, Indonesia \\ ${ }^{2}$ D-III Keperawatan, Stikes Payung Negeri Pekanbaru, Indonesia \\ Jalan Tamtama No.6 Kelurahan Labuh Baru Kecamatan Payung Sekaki Pekanbaru Riau \\ Telp. (0761) 885214
}

\begin{abstract}
Abstrak
Pandemi Covid-19 ditetapkan sebagai bencana non alam, yang mesti ditangani segera karena penularannya sangat cepat dan membahayakan manusia terutama kelompok khusus Ibu hamil, bersalin, Nifas dan Bayi Baru Lahir. Penambahan angka kejadian yang menimpa masyarakat dari hari kehari sangat memprihatinkan, masih adanya keluarga dan ibu nifas yang belum faham dalam PHBS, perawatan kesehatan ibu dan bayi pasca bersalin serta pencegahan penularan covid 19 ditatanan rumah tangga. Untuk meningkatkan peran serta keluarga dan pengetahuan ibu nifas dan tentang PHBS, perawatan kesehatan ibu dan bayi dan pencegahan penularan Covid-19 serta penerapannya selamasatu minggu pertama kelahiran bayinya dirumah. Pembinaan ini dilakukan April-Juni 2020pada 20 orang ibu post partum 6 jam, selama dirawat di klinik bidan dan saat pelayanan homecare dalam minggu pertama post partum, dengan memberikan edukasi (KIE), mengisi Kuesioner post test, dan pengamatan pelaksanaan tindakan perawatan ibu dan bayi serta pencegahan Covid 19 saat dirumah (homecare). Pengetahuan Post test baik 17 orang (85\%), Peran serta keluarga dalam PHBS meningkat 16 orang (80\%), Teknik Perawatan Ibu dan Bayi Baik 13 orang (65\%). Diharapkan agar Ibu Nifas dan keluarga tetap melaksanakan PHBS, perawatan ibu, bayi serta upaya pencegahan Covid 19 selama masa pandemic sesuai anjuran bidan.
\end{abstract}

Kata Kunci: pemberdayaan keluarga; pengetahuan; perawatan ibu dan bayi; pasca bersalin.

\begin{abstract}
Covid-19 pandemic is determined as non-natural disaster, because its rapid transmission and endanger humans, especially pregnant women, childbirth, post-partum, newborns. The increase ofincidence number that befall the community from day to day, there are still families and postpartum mothers who do not understand in postnatal maternal and infant health care and prevention of covid transmission 19. to increase family participation and knowledge of postpartum mothers about maternal and infant health care in the prevention of Covid-19 transmission and its application during the first week of her baby's birth at home. This coaching was implementating from April to June 2020 on 20 post partum mothers while being treated at the midwife clinic and during homecare services in the first week, by providing education, fill post-test questionnaire, observing the implementation of maternal and infants careand Covid 19 prevention at home. Family participation increased by 16 people (80\%), Post-Test Knowledge was good for 17 people (85\%), Good Mother and Baby Care Techniques for 13 people (65\%). It is hoped that postpartum motherswill continue to carry out maternal and infant care and prevention of Covid 19 during the pandemic period as suggested by the midwife.
\end{abstract}

Keywords: family empowerment; knowledge; maternal and infant care; postpartum delivery. 


\section{Pendahuluan}

Sejak World Health

Organization (WHO) menetapkan Corona Virus Desease 2019sebagai pandemic di dunia pada 11 maret 2020, maka Indonesia juga darurat Covid 19 sejak dikeluarkan Keppres nomor 7 tahun 2020 tentang Gugus Tugas Percepatan Penanganan Covid-19 (1).

Untuk menurunkan

prevalensi penularan Covid-19 kepada masyarakat luas, terutama pada kelompok khusus ibu hamil, bersalin dan nifas serta bayi baru lahir (BBL), maka peran tenaga kesehatan diharapkan dapat memberikan edukasi kepada masyarakat dalam hal pencegahan penularan Covid-19 seperti pemahaman dalam menjaga kebersihan diri dengan cuci tangan lebih sering, memakai masker, melakukan social distancing, mewaspadai gejala Batuk, Nyeri dada, sakit tenggorokan agar segera mendatangi petugas kesehatan. Protocol ini mesti diterapkan dengan benar dalam tatanan rumah tangga dengan menerapkan dan membudayakan perilaku hidup bersih dan sehat (PHBS) (2).

Selama kehamilan, bersalin, nifas dan BBL rentan terjadi komplikasi yang dapat diakibatkan oleh penyakit infeksi atau komplikasi langsung pada kondisi mereka, sehingga meningkatkan prevalensi kesakitan dan kematian ibu dan anak. Di Indonesia diperkirakan sekitar 38 ibu meninggal setiap hari akibat penyakit atau komplikasi akibat kehamilan, persalinan dan nifas(3).

Dalam masa normal saja masih terjadi masalah kesakitan dan kematian pada ibu maternal dan BBL, apalagi pada masa pandemic Covid-19 ini (4). Sekitar 13.7\% ibu hamil mengalami tanpa gejala, namun dapat saja menunjukkan hasil pemeriksaan PCR Covid 19 yang positif, oleh karena itu penolong persalinan mesti memakai alat pelindung diri (APD) minimal level 2 (5). Demikian juga dengan ibu nifas saat berada dirumah (stay at home) mesti tetap memperhatikan protocol kesehatan dalam pencegahan covid, karena ibu akan dapat menularkan kepada bayi yang akan disusuinya.

Pada Pedoman Bagi Ibu Hamil, Ibu Nifas, dan Bayi Baru Lahir selama Social Distancing, terdapat Protokol Layanan Kesehatan Ibu Dan Bayi Baru Lahir Selama PandemiCovid-19. Point 3 dijelaskan bahwa layanan pasca persalinan adalah Ibu dan keluarga mendapat nasihat dan edukasi tentang perawatan bayi baru lahir termasuk ASI ekslusif dan tanda bahaya jika ada penyulit pada bayi baru lahir dan jika terjadi infeksi masa nifas dan dianjurkan kalau kita membudayakan perilaku hidup bersih dan sehat, termasuk mencuci tangan bila habis melakukan sesuatu(2).

Perlunya penerapan PHBS dan menjaga kesehatan ibu dan bayi selama masa nifas akan dibutuhkan peran serta keluarga dalam mendukung keberhasilan ibu dalam menjalankan peran barunya sebagai ibu dan proses menyusui. Peran suami dan keluarga (orangtua, mertua, saudara, dan lain-lain) akan menjadikan ibu merasa nyaman menjalani masa nifas dengan tanpa beban terutama pada awal-awal pasca persalinan sampai satu bulan pertama, ini membutuhkan adaptasi dan penyesuaian bagi ibu(6). Perlu pengetahuan yang cukup bagi ibu dan suami /keluarga dalam Saat menjalani perubahan awal sebagai orangtua baru(7), ada hal-hal yang mesti difahami ibu dalam merawat 
kesehatannya dan bayinya, seperti asupan nutrisi seimbang, istirahat tidur yang cukup, olahraga teratur, hindari stress, proses perawatan BBL meliputi : Memandikan dan merawat tali pusat, pemberian ASI atau PASI, mengenali pola istirahat dan tidur bayi(8)(9).

$$
\text { Penerapan PHBS }
$$

dipengaruhi juga oleh peran orangtua, terutama ibu. Dalam rumah tangga ibu memiliki fungsi dan peran yang dominan dalam memberi contoh, teladan, pendidikan di suatu keluarga daripada ayah. Ibu sangat mendominasi dalam membuat menu makanan dan menjaga kebersihan rumah, termasuk didalam memberikan pendidikan kesehatan di keluarga(6) Masa pandemic ini kebijakan pemerintah untuk menjaga jarak social (social distancing), menjaga jarak fisik (physical distancing) , tinggal dirumah (stay at home) menjaga jarak untuk semua masyarakat ditempat umum(10). Tapi pada fakta dilapangan masih terdapat ketidakpatuhan masyarakat dalam mematuhi protokol tersebut. Masih terdapat ketidakpatuhan masyarakat dalam melaksanakan aturan yang ditetapkan baik ditempat umum.

$$
\text { Berdasarkan survey }
$$

pendahuluan dilakukan wawancara awal kepada $3 \mathrm{ibu}$ hamil trimester III dengan usia kehamilan> 36 minggu, menilai pemahaman mereka dalam pencegahan penularan Covid-19. Diketahui bahwa 1 orang keluar rumah untuk belanja harian ke warung menggunakan masker saat keluar rumah, sementara 2 orang tidak menggunakan masker.

Disamping itu pada 3 ibu post partum $<2$ bulan, yang berkunjung ke klinik bidan bahwa 2 orang persalinannya berlangsung normal dan 1 orang post seksio sesar, perawatan ibu dan BBL dilakukan oleh ibu dan keluarga seperti memandikan bayi, selama masa pandemic ini mereka stay at home, tapi tidak membatasi tamu yang datang melihat bayinya, jarang cuci tangan, jarang menggunakan masker dengan alasan mereka hanya berada didalam rumah saja.

Berdasarkan masalah diatas, maka tim Pengabdian Masyarakat merencanakan kegiatan Pengabdian Kepada Masyarakat (PKM) pada ibu-ibu pasca bersalin dan keluarganya tentang PHBS, Perawatan Ibu Dan Bayi Serta Pencegahan Penularan Covid-19 Di Bidan Praktek Mandiri tahun 2020.

\section{Metode Pelaksanaan}

Kegiatan PKM ini dilaksanakan sejak April - Juni 2020 terhadap ibu-ibu pasca bersalin dan keluarganya meliputi suami, ayah, ibu, mertua, kakak kandung, yang berada saat pelaksanaan kegiatan PKM. Jumlah pesertanya 20 orang, yang dipilih berdasarkan kecukupan jumlah sampel dan estimasi waktu serta kesediaan ibu untuk menjadi peserta.

Pelaksana kegiatan ini oleh tim PKM STIKes Payung Negeri dengan melibatkan 2 orang mahasiswa Kebidanan tingkat III.

Tempat Pelaksanaan kegiatan dilakukan di klinik BPM Islah wahyuni, dengan pertemuan dan pembinaan secara individu kepada ibu pasca bersalin 6 jam post partum dan keluarga, sampai seminggu dirumah melalui homecare service yang dilakukan :

a. 6 jam post partum : memberikan edukasi / penyuluhan kepada ibu dan keluarga, tentang segala sesuatu yang berkaitan dengan PHBS, Perawatan ibu dan bayi 
dirumah serta pencegahan penularan Covid-19, menggunakan leaflet dan media lembar balik meliputi :

- PHBS : Menjelaskan pentingnya pola hidup bersih sehat saat masa nifas ditatanan rumah tangga yaitu : makanan bergizi post partum, olahraga, istirahat tidur yang cukup

- Perawatan Ibu dan Bayi : Menjelaskan tentang proses laktasi dan cara menyusui bayi yang benar, Personal Higiene dan perawatan luka perineum, teknik memandikan bayi dan perawatan tali pusat, Deteksi dini masalah/komplikasi pada BBL.

- Mendemonstrasikan cara memandikan dan merawat tali pusat bayi dan meminta ibu untuk mengamati dan menanyakan hal-hal yang berhubungan dengan bayinya.

- Pencegahan penularan Covid-19 : menerangkan tentang pentingnya cuci tangan, memakai masker dan social distancing dan fisical distancing.

- Menjelaskan peran serta keluarga dalam PHBS, membantu menjaga kesehatan ibu dan bayi serta membantu mencegah penularan covid-19 dalam tatanan rumah tangga.

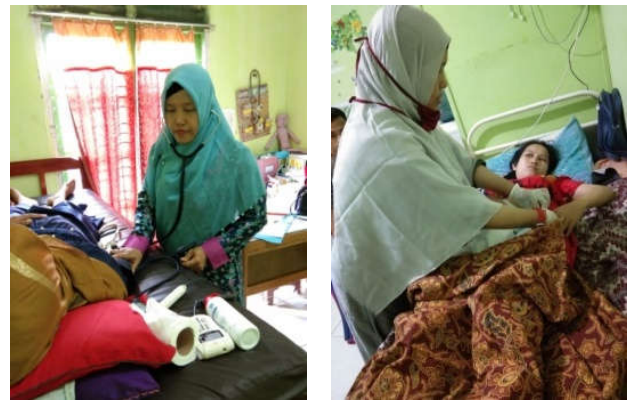

Gambar 1. Proses Pemeriksaan Fisik / Kondisi ibu post partum, pemberian Konseling Informasi dan Edukasi (KIE), yang dilakukan terhadap ibu post partum dan keluarga saat pasca persalinan di klinik BPM

b. Mengisi kuesioner pasca edukasi yang diberikan : untuk mengukur pemahaman dan pengetahuan yang sudah diberikan kepada ibu

- Meminta ibu-ibu pasca bersalin untuk mengisi kuesioner, sebagai bentuk evaluasi/post test pengetahuan ibu pasca pemberian edukasi / penyuluhan tentang segala sesuatu yang berkaitan dengan PHBS, Perawatan ibu dan bayi dirumah serta pencegahan penularan Covid-19.
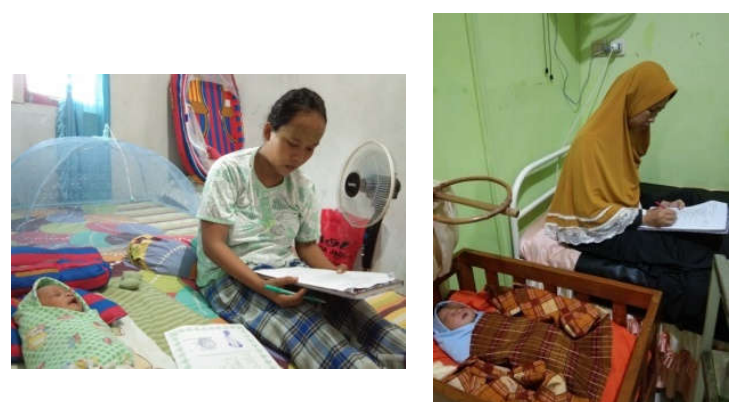

Gambar 2. Proses pengisian kuesioner pasca pemberian KIE pada Ibu post partum

c. Mengamati dan melihat pelaksanaan PHBS, Perawatan ibu dan bayi dirumah serta pencegahan penularan Covid-19 saat berada dirumah ibu nifas 
(ketika layanan homecare nifas) selama minggu pertama persalinannya dengan daftar checklist.

- Mengunjungi ibu selama 5 hari kerumah ibu, dan mengamati aktivitas ibu dalam menerapkan PHBS, menilai menu makanan, teknik menyusui bayi, memandikan bayi, mencuci tangan, penggunaan masker, social distancing dan fisical distancing dengan tamu yang berkunjung.Kegiatan observasi ini dilakukan berkelanjutan tiap hari selama 5 hari dipagi hari.

- Pemberdayaan keluarga: melihat peran serta keluarga dalam membantu meningkatkan penerapan PHBS, Perawatan ibu dan bayi dirumah serta pencegahan penularan Covid-19.
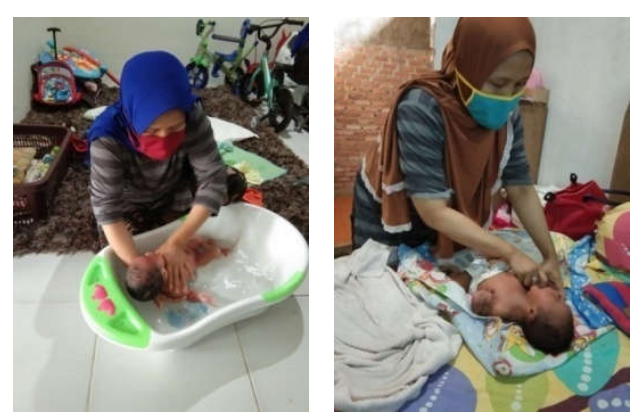

Gambar 3. Proses Observasi / pengamatan tentang perawatan ibu dan bayi baru lahir yang dilakukan secara individu saat pasca persalinan di rumah Pasien

\section{Hasil dan Pembahasan}

a) Hasil kegiatan

1. Data Umum

Karakteristik responden dalam PKM ini dapat dilihat pada tabel sebagai berikut :

Tabel 1.1. Distribusi Frekuensi Karakteristik Responden di BPM Islah Wahyuni

\begin{tabular}{|c|c|c|c|c|}
\hline No & Perilaku & $\mathbf{N}$ & Jumlah & Persentase (\%) \\
\hline \multirow[t]{4}{*}{1} & Umur & 20 & & \\
\hline & $\begin{array}{ll}-\quad<20 \\
\end{array}$ & & 0 & 0 \\
\hline & $-\quad 20-35$ & & 18 & 90 \\
\hline & $-35-45$ & & 2 & 10 \\
\hline \multirow[t]{4}{*}{2} & Pendidikan: & 20 & & \\
\hline & Pendidikan Dasar & & 9 & 45 \\
\hline & $\begin{array}{ll}- & \text { Pendidikan } \\
& \text { Menengah }\end{array}$ & & 10 & 50 \\
\hline & Pendidikan Tinggi & & 1 & 5 \\
\hline \multirow[t]{3}{*}{3} & Pekerjaan : & 20 & & \\
\hline & - $\quad$ Bekerja & & 2 & 10 \\
\hline & $\begin{array}{ll}\text { - } & \text { Tidak Bekerja }\end{array}$ & & 18 & 90 \\
\hline \multirow[t]{3}{*}{4} & Paritas & 20 & & \\
\hline & $\begin{array}{ll}\text { - } & \text { Primipara }\end{array}$ & & 13 & 65 \\
\hline & - $\quad$ Multipara & & 7 & 35 \\
\hline
\end{tabular}


Berdasarkan Tabel 1.1 dapat diketahui bahwa, mayoritas responden di BPM Islah Wahyuni Tahun 2020 berdasarkan umur mayoritas 20-35 tahun sebanyak 18 orang $(90 \%)$, mayoritas berpendidikan Menengah sebanyak 10 orang (50 \%), mayoritas tidak bekerja sebanyak 18 orang $(90 \%)$, mayoritas paritas ibu Primipara sebanyak 13 orang $(65 \%)$.

\section{Data khusus}

Tabel 1.2. Distribusi Frekuensi Pemberdayaan Ibu pasca bersalin dan keluarga di BPM Islah Wahyuni

\begin{tabular}{|c|c|c|c|c|}
\hline No & Perilaku & $\mathbf{N}$ & Jumlah & Persentase (\%) \\
\hline \multirow[t]{4}{*}{1} & Pengetahuan Ibu & 20 & & \\
\hline & - $\quad$ Baik & & 17 & 85 \\
\hline & - $\quad$ Cukup & & 3 & 15 \\
\hline & - $\quad$ Kurang & & 0 & 0 \\
\hline \multirow[t]{3}{*}{2} & PSM Keluarga: & 20 & & \\
\hline & - $\quad$ Meningkat & & 16 & 80 \\
\hline & - $\quad$ Kurang & & 4 & 20 \\
\hline \multirow[t]{3}{*}{3} & Teknik Perawatan Ibu dan bayi : & 20 & & \\
\hline & - $\quad$ Baik & & 13 & 65 \\
\hline & - $\quad$ Kurang & & 7 & 35 \\
\hline \multirow[t]{3}{*}{4} & Penerapan PHBS : & 20 & & \\
\hline & - $\quad$ Baik & & 16 & 80 \\
\hline & - Kurang & & 4 & 20 \\
\hline \multirow[t]{3}{*}{5} & Penerapan Pencegahan Covid-19: & 20 & & \\
\hline & - $\quad$ Baik & & 14 & 70 \\
\hline & - $\quad$ Kurang & & 6 & 30 \\
\hline
\end{tabular}

Berdasarkan Tabel 1.2 dapat diketahui bahwa, mayoritas responden di BPM Islah Wahyuni Tahun 2020 berdasarkan Pengetahuan Post test baik 17 orang $(85 \%)$, Peran serta keluarga dalam PHBS meningkat 16 orang $(80 \%)$, Teknik Perawatan Ibu dan Bayi Baik 13 orang (65\%). Penerapan PHBS oleh ibu dan keluarga baik 16 orang $(80 \%)$,

Penerapan Pencegahan Covid-19 baik 14 orang $(70 \%)$.

\section{b) Pembahasan}

Edukasi yang dilakukan pada masyarakat terkait penerapan Perilaku Hidup Bersih Sehat (PHBS), dirasakan sangat bermakna dan bermanfaat bagi Ibu pasca bersalin dan keluarga dalam tatanan rumah tangga, (6) terutama saat masa pandemic Covid-19 ini. Hal ini dikarenakan angka kejadian penambahan penderita Covid19terus bertambah. Data terbaru $(12 / 7)$ Kasus positif virus Corona di Indonesia bertambah 1.681 orang. Total kasus positif Covid-19 di Indonesia hingga hari ini mencapai 75.699 kasus 
Untuk meningkatkan kewaspadaan pada ibu dan bayi pasca bersalin menjaga diri agar tidak tertular dengan wabah Covid-19 dengan protokol kesehatan yang sudah ditetapkan seperti : Ibu menyusui dan pengasuh memahami penggunaan masker dan etika batuk, menjaga kebersihan diri dan lingkungan di rumah dan ketika berkunjung ke fasyankes, dan menyampaikan status Orang Dalam Pemantauan (ODP), Pasien Dalam Pengawasan (PDP) atau terkonfirmasi positif COVID-19 jika ada dilingkungan sekitar kita (2), serta diperlukan tindakan preventif agar selalu sehat dan dapat merawat diri dan bayinya dengan benar dengan penerapan PHBS yang tepat agar mencegah kejadian infeksi pada masa nifas (11).

Penelitian Trisnawati, 2018 tentang Pengaruh Perilaku Hidup Bersih Dan Sehat (PHBS) Masa Nifas Dengan Kejadian Infeksi Nifas Di Kabupaten Karawang, didapatkan hasil kejadian infeksi nifas sebanyak $28(29,8 \%)$ dan responden dengan Perilaku PHBS yang baik sebanyak 60 $(63,8 \%)$, terdapat hubungan yang bermakna antara PHBS dengan kejadian infeksi nifas dengan nilai $\mathrm{P}=0,040$.(11)

Perawatan diri yang benar dalam menjaga kesehatan masa nifas: pengetahuan dan sikap yang baik dalam merawat kesehatan pasca bersalin dan proses laktasi menyusui bayi yang tepat (6), nutrisi seimbang agar meningkatkan produksi ASI serta mempercepat penyembuhan luka, (13)olahraga ringan yang sesuai, kecukupan istirahat dan tidur (12).

Pelaksanaan PKM ini bertujuan membantu mewujudkan masyarakat yang sehat dan memiliki kualitas hidup yang baik. Masa pandemic yang sangat sulit ditebak kemana ujung dan akhirnya ini telah membuat perubahan fisik dan mental masyarakat Indonesia, ketakutan dan kekhawatiran yang berbesamayam dihati masyarakat, membuat dampak gangguan psikologis ringan sampai berat terjadi di belahan masyarakat lainnya. Hambatan ekonomi menjadi topik utama yang belum bisa dituntas dengan baik oleh keluarga sehingga ini mesti mendapatkan perhatian penuh dari pemerintah dan lembaga-lembaga kesehatan lainnya, bagaimana untuk mengedukasi masyarakat agar bisa mandiri dan berdaya guna dalam menghadapi masa pandemi Covid-19 ini.

Pada ibu pasca bersalin, jika dibiarkan begitu saja tentunya hal ini tidak bagus untuk kesehatan ibu dan bayinya karena berdampak pada kesehatan fisiknya, imunitas berkurang, asupan nutrisi yang tidak bagus, serta menurunkan kualitas hidup ibu dan bayinya. ASI berkurang sehingga gizi buruk bisa saja terjadi dan mengganggu proses tumbuh kembang anak kedepannya.

Dalam rangka mengimplementasikan hasil penelitian, menerapkan ilmu pengetahuan serta melakukan action nyata peduli masyarakat, maka kegiatan pengabdian kepada masyarakat yang ditaja oleh LPPM STIKes Payung 
Negeri yang dilaksanakan oleh para dosen pengajar diharapkan mampu membawa perubahan yang baik dan signifikan kepada masyarakat yang ada disekitarnya. Dosen diharapkan mampu menjadi role model dan penyambung lidah keinginan masyarakat dalam hal kesehatan yang belum mampu mereka jangkau selama ini.

Pelaksanaan pengabdian ini mengangkat tema pemberdayaan Ibu pasca bersalin dan keluarga dalam meningkatkan pengetahuan dan pemahaman mereka dalam PHBS, Perawatan Ibu dan bayi pasca bersalin serta upaya pencegahan penularan Covid-19 selama seminggu pertama kelahiran di Bidan Praktek Mandiri Islah Wahyuni.

Untuk membuktikan perubahan sikap dan perilaku mereka, maka tim PKM melakukan pengamatan / observasi saat pelayanan homecare di rumah pasien, hal ini dikarenakan klinik bidan ini memang ada fasilitas pelayanan homecare pasca bersalin pada ibu dan bayi, sebagai bentuk lain pelaksanaan kunjungan Nifas.

Pelaksanaan kegiatan ini telah berlangsung selama 3 bulan (April-Juni 2020), sampai tercukupinya jumlah pasien yang telah dibina dan diajarkan tentang pengetahuan dan pemahaman mereka dalam PHBS, Perawatan Ibu dan bayi pasca bersalin serta upaya pencegahan penularan Covid19.

Hasil positif dari kegiatan PKM ini dirasakan oleh peserta seperti peningkatan pemahaman dan pengetahuan ibu baik 17 orang (85\%), kesadaran dan prilaku PHBS ibu dan keluarga dalam masa pandemic ini, adanya sambutan baik dari keluarga dan dukungan keluarga dalam menciptakan kondisi kondusif terkait pelaksanaan PHBS didalam tatanan rumah tangganya, ditandai dengan meningkatnya Peran serta keluarga dalam PHBSyaitu 16 orang (80\%), Penerapan PHBS oleh ibu dan keluarga baik 16 orang $(80 \%)$, Penerapan Pencegahan Covid-19 baik 14 orang $(70 \%)$.

Hal ini menandakan bahwa mereka memiliki animo dan kesadaran/awareness yang tinggi dalam menyadari perubahan lingkungan yang tidak mendukung pada masa pandemic ini bagi kesehatan ibu, bayi dan keluarga, dan tentunya ini mesti kita appresiasi dengan adanya pembinaan dan pemberian dukungan berupa informasi seputar kesehatan sesuai dengan kebutuhan dan kondisi mereka masa pandemi ini.

Terlepas dari itu semua, tim PKM juga memberikan contoh dalam setiap tindakan yang disampaikan, dimana saat diklinik, tim PKM dkk menerapkan APD level 2 (masker, faceshield, handscoon) dalam berkontak fisik, menjaga jarak dengan pasien, dan memperlihatkan bagaimana cara cuci tangan yang benar sebelum dan setelah bekerja. Senantiasa mengingatkan ibu untuk menilai perubahan fisiknya seperti apakah ada demam, batuk, nyeri dada, nyeri tenggorokan, dan lain-lain.

Tidak ada hambatan dan halangan berarti yang ditemui 
saat proses pembinaan dan pelaksanaan PKM di masa pandemic ini, kecuali hanya menjaga kehati-hatian dalam bekerja dan menjalankan protokol kesehatan yang sudah ditetapkan dengan cermat dan tepat, sehingga selalu menjaga diri tidak menjadi penyebab penularan infeksi penyakit ataupun penularan covid-19 kepada ibu pasca bersalin dan keluarganya.

\section{Kesimpulan}

Pengabdian masyarakat yang dilaksanakan selama April-Juni 2020 ini pada $20 \mathrm{ibu}$ pasca bersalin dan keluarganya di klinik Bidan Praktek Mandiri Islah Wahyuni, dibantu oleh dua orang mahasiswa Kebidanan tingkat III telah berjalan sukses dan lancar, adanya perubahan bermakna yang didapatkan dari kegiatan ini terhadap perubahan perilaku Pengetahuan Ibu dan keluarga PHBS, cara perawatan ibu dan bayi serta teknik mencegah penularan Covid-19 selama masa pandemic ini. dimana hasilnya adalah : Pengetahuan Post test baik 17 orang $(85 \%)$, Peran serta keluarga dalam PHBS meningkat 16 orang $(80 \%)$, Teknik Perawatan Ibu dan Bayi Baik 13 orang (65\%). Penerapan PHBS oleh ibu dan keluarga baik 16 orang (80\%), Penerapan Pencegahan Covid-19 baik 14 orang $(70 \%)$.

Diharapkan kedepannya ibu dan keluarga dapat mempertahankan perilaku PHBS yang sudah diterapkan dengan benar didalam tatanan rumah tangga sehingga mencegah penularan infeksi nifas dan penularan Covid-19 dalam lingkungan rumah tangganya.

\section{Daftar Pustaka}

[1] Keppres No. 7 Tahun 2020. Keputusan Presiden RI No. 7 Tahun 2020 Tentang Gugus Tugas Percepatan Penanganan Corona Virus Disease 2019 (COVID-19). 2020; 2019 (0107): 1-8.

[2] RI KK. Pedoman Bagi Ibu Hamil, Ibu Nifas, dan Bayi Baru Lahir selama Social Distancing. pp.9-12, 2020.

[3] Achadi EL. Kematian Maternal dan Neonatal di Indonesia. Rakerkernas 2019. pp.1-47, 2019.

[4] POGI. Rekomendasi Penanganan Infeksi Virus Corona (Covid-19) Pada Maternal (Hamil, Bersalin Dan Nifas). Penanganan Infeksi Virus Corona Pada Matern. 1(3), pp. 9-11, 2020. [Online] https://pogi.or.id/publish/reko mendasi-penanganan-infeksivirus-corona-covid-19-padamaternal/

[5] Rekomendasi Penanganan Infeksi Virus Corona (COVID19) Pada Maternal [Online] https://pogi.or.id/publish/reko mendasi-penanganan-infeksivirus-corona-covid-19-padamaternal/

[6] Rayhana, Rini Astin T. Hubungan Karakteristik, Pengetahuan dan Sikap terhadap Perilaku Hidup Bersih dan Sehat pada Ibu Rumah Tangga di Kelurahan Kebalen Kecamatan Babelan Bekasi Utara. J Kedokt dan Kesehat. 12(2): 168-80, 2016. [Online]. https:/jurnal.umj.ac.id/index.p $\mathrm{hp} / \mathrm{JKK} /$ article/view/1562/136 
[7] Nurrahmaton N, Sartika D. Hubungan Pengetahuan Ibu Post Partum Tentang Perawatan Luka Perineum dengan Proses Penyembuhan Luka di Klinik Bersalin $\mathrm{Hj}$. Nirmala Sapni, Amkeb Medan. J Bidan Komunitas. 1(1):20, 2018

[8] Kemenkes. Buku Saku Pelayanan Kesehatan Neonatal Esensial. xviii, 2010. [Online] http://www.gizikia.depkes.go.i d/wpcontent/uploads/downloads/20 11/09/Buku-Saku-PelayananKesehatan-NeonatalEsensial.pdf

[9] Kementerian Kesehatan. No. HK.02.01-MENKES-335-2020 ttg Protokol Pencegahan COVID-19 Tempat Kerja Sektor Jasa dan Perdagangan. 2020;1-4.

[10] Shannon, Claude Elwood, Indira $\mathrm{T}$, Somakim $\mathrm{S}$, Susanty E, Alamiah US, et al. No Title. Math Educ J. 1(1):75, 2018. [Online].

http://dx.doi.org/10.1016/j.biot echadv.2010.07.003\%0Ahttp:// dx.doi.org/10.1016/j.scitotenv. 2016.06.080\%0Ahttp://dx.doi. org/10.1016/j.bbapap.2013.06. 007\%0Ahttps://www.frontiersi n.org/article/10.3389/fmicb. 20 18.02309/full\%0Ahttp://dx.doi .org/10.1007/s13762-
[11] Creti L, Libman E, Rizzo D, Fichten CS, Bailes S, Tran D$\mathrm{L}$, et al. Sleep in the Postpartum: Characteristics of First-Time, Healthy Mothers. Sleep Disord. 2017. pp.1-10, 2017.

[12] Range MH. ar e Lt d ar e Pe Lt d. 2018; 